\title{
Impact of maternal iron deficiency on quality and quantity of milk ingested by neonatal rats
}

\author{
BY DEBORAH L. O'CONNOR, MARY FRANCES PICCIANO* \\ AND ADRIA R. SHERMAN \\ School of Human Resources and Family Studies and Division of Nutritional Sciences, \\ College of Agriculture, University of Illinois, Urbana, IL 61801, USA
}

(Received 12 February 1988-Accepted 21 April 1988)

1. The effect of maternal iron deficiency on milk composition and consumption by sucking rats was investigated.

2. Dams ( $n$ 42) were fed on semi-purified diets with either $8(\mathrm{Fe}-)$ or $250(\mathrm{Fe}+) \mathrm{mg} \mathrm{Fe}$ as ferrous sulphate $/ \mathrm{kg}$ throughout gestation and lactation. Total milk intake was determined at days 7,12 and 17 of lactation from the rate of disappearance of ${ }^{3} \mathrm{H}_{2} \mathrm{O}$ from the total body water pool of pups. Measurements of milk constituents and $\mathrm{Fe}$ status of animals also were made.

3. Feeding the $\mathrm{Fe}$ - diet led to the development of anaemia in dams and pups and to growth retardation of sucking pups.

4. Concentrations of total lipid and $\mathrm{Fe}$ in milk from $\mathrm{Fe}-$ dams were significantly lower than those from $\mathrm{Fe}+$ dams. Mean milk intakes $(\mathrm{ml} / \mathrm{d})$ of Fe-deficient pups were 21 and $28 \%$ less than intakes of Fe-sufficient pups on days 12 and 17 respectively. However, when expressed per $\mathrm{kg}$ body-weight, mean milk intakes were similar between groups on days 17 and 12 and increased by $47 \%$ in the Fe-deficient group on day 17 of lactation.

5. It is concluded that maternal Fe deficiency affects the quality of milk ingested by neonatal rats. However, Fe-deficient pups are at least partially able to compensate for reduced milk energy and nutrient contents by increasing intake in late lactation.

Iron deficiency, the most common nutritional disorder, is estimated to afflict $10-20 \%$ of the population worldwide (Bothwell et al. 1979). Infants and pregnant women are particularly vulnerable to developing Fe deficiency because of high demands for Fe during these stages of the life cycle (Dallman et al. 1975; Bothwell et al. 1979). Infants are at greatest risk because their principal and often only source of nutrition is milk, which is notoriously low in Fe (Picciano \& Guthrie, 1976; Picciano et al. 1981). In the rat, maternal Fe deficiency results in a decrease in the concentration of milk Fe (Bartholmey \& Sherman, 1985). However, the possible effects of maternal Fe deficiency on milk production and concentrations of major milk constituents have not been examined.

Recent results from our laboratory show that folate incorporation into milk is considerably reduced in severely and moderately Fe-deficient animals (O'Connor et al. $1987 a$ ). In addition to the development of anaemia, pups nursed by Fe-deficient dams show marked growth retardation. Whether this growth retardation results entirely from altered milk composition or from the combined effects of poor milk quality and decreased milk intake has not been examined. Provision of protein-deficient diets to lactating rats reduces milk output, demonstrating that maternal nutriture has a direct impact on the quality of milk available to the sucking pups (Venkatachalam \& Ramanathan, 1964; Menaker \& Navia, 1973). Similar relations between maternal nutrition, milk composition and output are evident in human beings. Jelliffe \& Jelliffe (1978) reported that milk production may be reduced by as much as $40 \%$ in severe protein, energy, or protein-energy malnutrition. Miranda et al. (1983) observed a two-thirds reduction in the protein content of colostrum and a suppression of several immunologic factors in milk samples from malnourished Colombian women.

$$
\text { * For reprints. }
$$


Table 1. Basal diet composition $(\mathrm{g} / \mathrm{kg})$

\begin{tabular}{llc}
\hline \hline Ingredient & Amount \\
\hline Casein* & 220 \\
Sucrose & 300 \\
Maize starch & 315 \\
Maize oil & 100 \\
Cellulose $\ddagger$ & 20 \\
Vitamin mix§ & 10 \\
Iron-free AIN-76 mineral mix $\|$ & 35 \\
\hline
\end{tabular}

* Vitamin-free test casein (Teklad, Madison, WI).

$\uparrow$ Mrs Tucker's pure maize oil (Anderson Clayton Foods, Dallas, TX).

\# Alphacel (ICN Nutritional Biochemical Co., Cleveland, OH).

$\S$ No. 40060 (Teklad) composition of vitamin mix $(\mathrm{mg} / \mathrm{kg}$ diet) : $P$-aminobenzoic acid $110 \cdot 1$, ascorbic acid, coated $(97.5 \%) 991.2$, biotin 0.441 , vitamin $B_{12} 29 \cdot 7$, calcium pantothenate 66.1 , choline 0.1443 , pteroylmonoglutamic acid 1.98 , inositol $110 \cdot 1$, menadione $49 \cdot 6$, riboflavin 22.0 , niacin $99 \cdot 1$, pyridoxine hydrochloride $22 \cdot 0$, thiamin hydrochloride $22 \cdot 0$, dry retinyl palmitate $39 \cdot 6$, dry ergocalciferol $4 \cdot 405$, dry tocopheryl acetate $242 \cdot 3$. maize starch $4 \cdot 7 \mathrm{~g}$.

$\|$ AIN-76 mineral mix prepared without $\mathrm{Fe}$. Composition of mineral mix (g/ $\mathrm{kg}$ mineral mix): $\mathrm{CaHPO}_{4} \mathrm{dibasic}$ $500 \cdot 0, \mathrm{NaCl} 74 \cdot 0$, potassium citrate monohydrate $220 \cdot 0, \mathrm{~K}_{2} \mathrm{SO}_{4} 52 \cdot 0, \mathrm{MgO} 24 \cdot 0, \mathrm{ZnCO}_{3} 1 \cdot 6, \mathrm{MnCO}_{3} 3 \cdot 5$, cupric carbonate $0.485, \mathrm{KIO}_{3} 0.01, \mathrm{Na}_{2} \mathrm{SeO}_{3} .5 \mathrm{H}_{2} \mathrm{O} 0.01, \mathrm{CrK}\left(\mathrm{SO}_{4}\right)_{2} .12 \mathrm{H}_{2} \mathrm{O} 0.55$, sucrose $124.03 . \mathrm{FeSO}_{4} .7 \mathrm{H}_{2} \mathrm{O}$ was added to the diets at the expense of sucrose to provide the desired Fe concentrations.

The present study was designed to investigate the influence of maternal Fe deficiency on the quality and quantity of milk delivered to sucking rat pups. Specifically, we measured milk intake, and milk contents of protein, amino acids, total lipid, ash and Fe and calculated energy intakes of Fe-sufficient and Fe-deficient rat pups.

\section{METHODS AND MATERIALS}

\section{Animal care and dietary treatments}

Virgin Sprague-Dawley rats (Harlan Industries, Indianapolis, IN), weighing 150-170 g, were housed in suspended, stainless-steel, wire-mesh cages in a room with controlled temperature, humidity (less than $40 \%$ relative humidity at $22^{\circ}$ ) and light ( $12 \mathrm{~h} \mathrm{light}$ cycle). Rats were acclimatized for 2 weeks before breeding and fed on a non-purified ration (Purina Rodent Chow; Ralston Purina Co., St Louis, MO) and tap water. Animals weighing between 180 and $220 \mathrm{~g}$ were mated. Pregnancy (day 1) was confirmed by the presence of vaginal plugs and sperm. On day 1 of pregnancy, rats $(n 42)$ were randomly assigned to one of two experimental dietary treatments: Fe-sufficient $(\mathrm{Fe}+)$ and $\mathrm{Fe}$ deficient $(\mathrm{Fe}-)$.

The two experimental diets (Table 1) were formulated to be nutritionally adequate for reproduction in the rat, except for $\mathrm{Fe}$ (National Research Council, 1978). Direct analyses confirmed dietary $\mathrm{Fe}$ concentrations of $8 \mathrm{mg} / \mathrm{kg}(\mathrm{Fe}-)$ and $250 \mathrm{mg} / \mathrm{kg}(\mathrm{Fe}+)$. Demineralized water (Nanopure, Barnstead, Boston, MA) and the experimental diets were fed ad lib. At $2 \mathrm{~d}$ before the expected date of delivery, dams were placed in large maternity cages in which a smaller pup cage containing Fe-free bedding was placed (San-i-cel; Paxton Processing Co., Paxton, IL). Litters were culled to seven pups (four males and three females) on day 2 of lactation. Dams were permitted to nurse their young (seven pups per litter) until day 7,12 or 17 of lactation (seven litters per dietary treatment at each stage of lactation measured). Food and water were positioned exterior to the inner pup cage so that only the dams had access to them. 


\section{Milk intake determination}

On the mornings of days 4,9 and 14 , immediately following the $12 \mathrm{~h}$ dark cycle, pups were separated from dams and ear-notched to enable identification. Five pups in each litter were given a 30-50 $\mu 1$ subcutaneous injection (amount depending on age) of a tritiated physiological saline ( $9 \mathrm{~g}$ sodium chloride/1) solution $(50 \mathrm{Ci} / 1$; Amersham, Arlington Heights, IL). Two pups in each litter were sham injected with unlabelled physiological saline. This dose of radioactivity was chosen to permit a reliable measurement of isotope recycling among dams and pups. At 24,48 , and $72 \mathrm{~h}$ after injection, each pup was weighed and a $10 \mu \mathrm{l}$ tail blood sample taken and placed in $10 \mathrm{ml}$ scintillation cocktail (Beckman LS9000, Fullerton, CA). This procedure resulted in a total water intake measurement for two consecutive days. Immediately following the collection of tail blood, two litters in each treatment group at each experimental period were killed by cervical dislocation, cut open, frozen and freeze dried (Labconco Co., Kansas City, MO) for determination of total body water. Total water intake was estimated as described by Coward et al. (1982), using the following equation to calculate the disappearance of ${ }^{3} \mathrm{H}_{2} \mathrm{O}$ from the total body water pool:

$$
\text { Total water intake }=\frac{Q_{1}-Q_{2}}{\log Q_{1} / Q_{2}} \times \log C_{1} / C_{2},
$$

where $Q$ represents total body water volume of the pup, $C$ the specific activity of ${ }^{3} \mathrm{H}_{2} \mathrm{O}$ in whole blood at the beginning $\left(Q_{1}, C_{1}\right)$ and end $\left(Q_{2}, C_{2}\right)$ of the water intake measurement period. Since packed cell volume values did not change more than $2.5 \%$ in both control and experimental groups over the period of measurement, it was not necessary to alter this equation for the determination of total water intake in the Fe-deficient group. For the measurement of total milk intake, values for total water intake were corrected for the water produced from the oxidation of protein, fat and carbohydrate in the milk samples (Bergmann et al. 1974).

\section{Milk and tissue collection}

Approximately $1 \mathrm{~h}$ after tail blood collection from pups, dams were injected with ketamine hydrochloride (Ketaset; Bristol Laboratories, Syracuse, NY; $1.0 \mathrm{ml} / \mathrm{kg}$ ) and oxytocin (Sigma Co., St Louis, MO; 2.5 UPS units $/ \mathrm{kg}$ ) to facilitate milking. Milk was expressed from the mammary gland by gentle massaging and collected by flexible capillary tubing using a suction apparatus. The tube in which milk was collected was kept on ice. Samples of milk and tissues were partitioned among several containers and stored at $-70^{\circ}$ before analyses. After milking, dams and remaining litter mates were anaesthetized with chloroform and blood collected by cardiac puncture. Livers were removed and rinsed with demineralized water, blotted dry and weighed.

\section{Milk and tissue biochemical analyses}

The total water content of milk was determined by weighing $500 \mu \mathrm{l}$ of milk before and after drying overnight $\left(60^{\circ}\right)$. Ash content was determined after the dried milk sample was oxidized in a muffle furnace for $12 \mathrm{~h}$ at $550^{\circ}$. The protein content of milk samples was estimated using the BCA protein assay (Pierce Chemical Co., Rockford, IL) and bovine plasma no. 909 as the reference standard (National Bureau of Standards, Gaitherburg, MD) (Keller \& Neville, 1986). Amino acid analyses were performed after 21 h hydrolysis of milk samples in $6 \mathrm{M}$-hydrochloric acid at $100^{\circ}$ using a Beckman $119 \mathrm{CL}$ amino acid analyser (Fullerton, CA). Milk fat determinations were measured using the creamatocrit method as described by Lucas et al. (1978). The latter procedure was standardized using a 
Table 2. Mean body-weight and measurements of iron status of dams and pups (Mean values with their standard errors for seven dam samples and five pooled litter (seven pups/litter) samples)

\begin{tabular}{|c|c|c|c|c|c|c|c|}
\hline & \multirow{3}{*}{$\begin{array}{c}\text { Dietary } \\
\text { Fe } \\
(\mathrm{mg} / \mathrm{kg})\end{array}$} & \multicolumn{6}{|c|}{ Post-natal day } \\
\hline & & \multicolumn{2}{|c|}{7} & \multicolumn{2}{|c|}{12} & \multicolumn{2}{|c|}{17} \\
\hline & & Mean & SEM & Mean & SEM & Mean & SEM \\
\hline \multicolumn{8}{|l|}{ Dams: } \\
\hline Initial body- & 250 & 191 & 3 & 193 & 3 & 194 & 4 \\
\hline wt (g) & 8 & 196 & 6 & 202 & 4 & 190 & 2 \\
\hline Final body- & 250 & 245 & 5 & 226 & 10 & 254 & 5 \\
\hline $\mathrm{wt}^{\mathrm{a}, \mathrm{b}}(\mathrm{g})$ & 8 & 261 & 5 & $270^{* * *}$ & 6 & 245 & 6 \\
\hline Haemoglobin ${ }^{a}$ & 250 & 132 & 2 & 135 & 6 & 141 & 2 \\
\hline$(\mathrm{g} / 1)$ & 8 & $89^{* * *}$ & 3 & $97 * * *$ & 4 & $101 * * *$ & 2 \\
\hline Liver $\mathrm{Fe}$ & 250 & $516 \cdot 3$ & $40 \cdot 4$ & $495 \cdot 6$ & $48 \cdot 4$ & $555 \cdot 8$ & $67 \cdot 6$ \\
\hline$(\mu \mathrm{g} / \mathrm{g}$ dry wt) & 8 & $115 \cdot 3^{* * *}$ & $26 \cdot 7$ & $178 \cdot 2 * * *$ & $26 \cdot 3$ & $140 \cdot 8 * * *$ & $17 \cdot 5$ \\
\hline \multicolumn{8}{|l|}{ Pups: } \\
\hline Day 2 body- & 250 & $6 \cdot 7$ & 0.1 & $6 \cdot 1$ & 0.4 & $6 \cdot 5$ & 0.2 \\
\hline wt (g) & 8 & 6.0 & $0 \cdot 3$ & 5.9 & 0.2 & $6 \cdot 5$ & 0.6 \\
\hline Final body- & 250 & $14 \cdot 4$ & 0.2 & $25 \cdot 8$ & 1.0 & $43 \cdot 4$ & 1.7 \\
\hline$w t^{a, b}(g)$ & 8 & $11 \cdot 5^{*}$ & 0.8 & $19 \cdot 0^{* * *}$ & 1.0 & $22 \cdot 0^{* * *}$ & 1.6 \\
\hline Haemoglobin ${ }^{a, b}$ & 250 & 72 & 3 & 89 & 5 & 93 & 3 \\
\hline$(\mathrm{g} / 1)$ & 8 & $49^{* * *}$ & 2 & $39 * * *$ & 3 & $50^{* * *}$ & 2 \\
\hline Liver $\mathrm{Fe}$ & 250 & $293 \cdot 9$ & $28 \cdot 4$ & $166 \cdot 9$ & 14.9 & $91 \cdot 0$ & 150 \\
\hline$(\mu \mathrm{g} / \mathrm{g}$ dry wt $)$ & 8 & $64 \cdot 1^{* * *}$ & $23 \cdot 2$ & $74 \cdot 8^{*}$ & $21 \cdot 1$ & $92 \cdot 1$ & $39 \cdot 0$ \\
\hline
\end{tabular}

Analysis of variance $\left(2 \times 3\right.$ factorial): ${ }^{a}$ significant $(P<0 \cdot 05)$ time effect, ${ }^{\mathrm{b}}$ significant $(P<0 \cdot 05)$ interaction. Comparisons between treatments were made using least significant difference tests. Differences between dietary treatment groups at each time were significant: ${ }^{*} P<0.05,{ }^{* *} P<0.01,{ }^{* * *} P<0.001$.

modified Folch method for total lipid analyses (Timmen \& Dimick, 1972). Carbohydrate content was calculated by difference for the purposes of correcting water intake values for the measurement of milk intake and for the estimation of pup energy intake.

Haemoglobin $(\mathrm{Hb})$ concentrations were determined in whole blood by the cyanomethaemoglobin method (Richterich, 1969) using prepared reagents and standards (Sigma Diagnostics, St Louis, MO). Livers were dried to a constant weight $\left(90^{\circ}\right)$ and ashed $\left(550^{\circ}\right)$ for a total of $24 \mathrm{~h}$. Nitric acid and two drops of a potassium sulphate solution (100 g/l) were used to facilitate ashing. Ashed diets, milk and livers were analysed for Fe using atomic absorption spectrophotometry (Allied Analytical Systems Model no. 951; Waltham, MA). Accuracy and reproducibility of analytical procedures for Fe determinations were assessed using orchard leaves no. 1571 and bovine liver no. 1577 as standard reference materials (National Bureau of Standards).

\section{Statistical analyses}

Results were evaluated using analysis of variance statistics $(2 \times 3$ factorial $), F$ tests, least significant difference tests and $t$ tests (Steel \& Torrie, 1980; SAS Institute Inc., 1985). Where not shown otherwise, a value of $P<0.05$ was taken to be statistically significant. 
Table 3. Mean proximate constituents and amino acid profiles following acid hydrolysis of milk samples from Fe-sufficient and Fe-deficient rats during lactation

(Statistical analyses indicated no significant effect of stage of lactation on nutrient composition, therefore, pooled treatment means are presented for purposes of clarity. Values are for thirteen to twenty samples with their standard errors except for amino acid profiles which were performed on four samples/ treatment)

\begin{tabular}{|c|c|c|c|c|}
\hline \multirow[b]{3}{*}{ Milk } & \multicolumn{4}{|c|}{ Dams fed } \\
\hline & \multicolumn{2}{|c|}{$250 \mathrm{mg} \mathrm{Fe} / \mathrm{kg}$} & \multicolumn{2}{|c|}{$8 \mathrm{mg} \mathrm{Fe} / \mathrm{kg}$} \\
\hline & Mean & SEM & Mean & SEM \\
\hline Water $(\mathrm{g} / \mathrm{kg})$ & $604 \cdot 7$ & $11 \cdot 5$ & $634 \cdot 1$ & $13 \cdot 6$ \\
\hline Fat $(\mathrm{g} / \mathrm{kg})$ & $269 \cdot 5$ & $11 \cdot 3$ & $204 \cdot 5^{*}$ & $10 \cdot 0$ \\
\hline Ash $(\mathrm{g} / \mathrm{kg})$ & 1.6 & $0 \cdot 1$ & 1.9 & $0 \cdot 1$ \\
\hline $\mathrm{Fe}(\mathrm{mg} / \mathrm{kg})$ & $8 \cdot 7$ & $2 \cdot 2$ & $3 \cdot 7^{*}$ & $0 \cdot 4$ \\
\hline Protein $(\mathrm{g} / \mathrm{kg})$ & $142 \cdot 8$ & $12 \cdot 5$ & $128 \cdot 1$ & $9 \cdot 9$ \\
\hline \multicolumn{5}{|c|}{ Amino acid profile $(\mathrm{nmol} / \mathrm{l})$} \\
\hline Aspartic acid & $75 \cdot 6$ & $4 \cdot 8$ & $72 \cdot 6$ & $3 \cdot 9$ \\
\hline Threonine & $38 \cdot 5$ & $2 \cdot 6$ & $36 \cdot 3$ & $1 \cdot 7$ \\
\hline Serine & $87 \cdot 0$ & $5 \cdot 0$ & $83 \cdot 6$ & $4 \cdot 7$ \\
\hline Glutamic acid & $162 \cdot 6$ & $10 \cdot 6$ & $152 \cdot 8$ & $8 \cdot 8$ \\
\hline Proline & $63 \cdot 3$ & $8 \cdot 4$ & $48 \cdot 3$ & $9 \cdot 1$ \\
\hline Glycine & $22 \cdot 0$ & $1 \cdot 7$ & $20 \cdot 5$ & 1.4 \\
\hline Alanine & $64 \cdot 5$ & $3 \cdot 7$ & $52 \cdot 2$ & 7.9 \\
\hline Valine & $44 \cdot 1$ & $3 \cdot 0$ & $38 \cdot 3$ & $2 \cdot 7$ \\
\hline Methionine & 11.9 & 0.8 & 16.4 & $4 \cdot 2$ \\
\hline Isoleucine & $35 \cdot 2$ & $2 \cdot 1$ & $30 \cdot 1$ & $3 \cdot 7$ \\
\hline Leucine & 82.0 & $4 \cdot 7$ & $89 \cdot 1$ & $11 \cdot 0$ \\
\hline Tyrosine & $22 \cdot 4$ & $1 \cdot 3$ & $21 \cdot 4$ & $0 \cdot 9$ \\
\hline Phenylalanine & $28 \cdot 2$ & 1.6 & $26 \cdot 3$ & $1 \cdot 1$ \\
\hline Histidine & $17 \cdot 5$ & $0 \cdot 9$ & 16.5 & 0.8 \\
\hline Lysine & $45 \cdot 6$ & $3 \cdot 1$ & 43.5 & 1.9 \\
\hline Arginine & $22 \cdot 3$ & 1.6 & $21 \cdot 1$ & 0.9 \\
\hline
\end{tabular}

Differences between dietary groups were significant $(t$ test $):{ }^{*} P<0 \cdot 05$.

\section{RESULTS}

Maternal feed intake, body-and organ weights

Values summarizing changes in maternal and pup body-weights during lactation are shown in Table 2. Dietary Fe concentration had no effect on food consumption or body-weight of dams during reproduction except at day 12 of pregnancy when Fe-deficient dams weighed $19 \%(P<0.001)$ more than control animals. Pups in the experimental group $(\mathrm{Fe}-)$ were smaller than those in the control group $(\mathrm{Fe}+)$ on days 7,12 and 17 , with $\mathrm{Fe}-$ pups weighing $20(P<0.05), 26(P<0.001)$ and $49 \%(P<0.001)$ less than age-matched $\mathrm{Fe}+$ pups respectively. Mean liver weights (values not shown) of $\mathrm{Fe}-$ pups were also reduced by $16 \cdot 1-39 \cdot 3 \%(P<0 \cdot 01)$. In contrast, no differences in body-weight were found between $\mathrm{Fe}+$ and $\mathrm{Fe}-$ pups on day 2 of lactation.

\section{Fe status}

Mean $\mathrm{Hb}$ concentrations for both dams and their pups strongly reflected the $\mathrm{Fe}$ concentration of the diets fed to dams (Table 2). Both dams and pups in the experimental group $(8 \mathrm{mg} \mathrm{Fe} / \mathrm{kg})$ showed evidence of severe $\mathrm{Fe}$ deficiency anaemia with mean $\mathrm{Hb}$ 

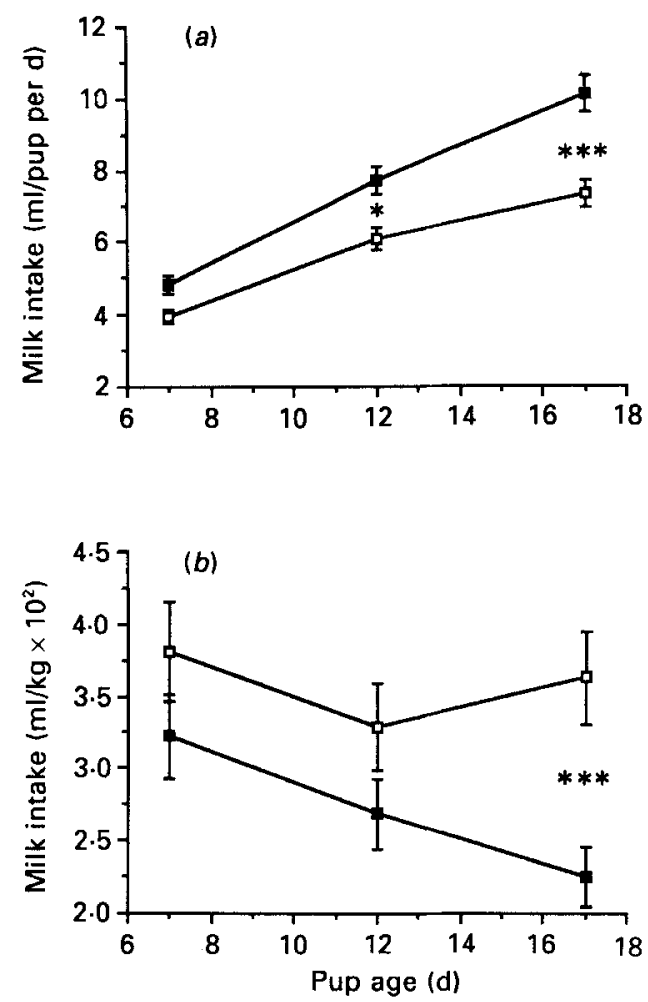

Fig. 1. Mean daily milk intake expressed as $(a) \mathrm{ml} / \mathrm{pup}$ and $(b) \mathrm{ml} / \mathrm{kg}$ body-weight of Fe-sufficient ( and Fe-deficient $(\square)$ sucking rats. Points are means with their standard errors represented by vertica! bars. Differences between dietary treatment groups were significant: ${ }^{*} P<0.05,{ }^{* * *} P<0.001$.

concentrations less than $30 \%$ of animals in the control group $(P<0.001)$. Hb concentrations for both $\mathrm{Fe}+$ and $\mathrm{Fe}-$ dams and $\mathrm{Fe}+$ pups increased as lactation progressed. In contrast, $\mathrm{Hb}$ concentrations decreased between days 7 and 14 in $\mathrm{Fe}-$ pups. Except on day 17, mean liver Fe concentrations in $\mathrm{Fe}-$ pups were $20 \%$ less than concentrations in control pups $(P<0.05)$.

\section{Milk composition}

Mean milk Fe concentration from $\mathrm{Fe}-$ dams was $57 \%(P<0.05)$ lower than that from control animals (Table 3). Proximate analysis of milk samples showed that milk from $\mathrm{Fe}-$ dams was $24 \%$ lower in fat than milk from Fe + dams $(P<0.05)$. Measurements of water, ash, protein and amino acids of milk samples from control and experimental animals were similar.

\section{Milk intake}

Daily milk intake expressed as $\mathrm{ml} / \mathrm{pup}$ and $\mathrm{ml} / \mathrm{kg}$ body-weight is summarized in Fig. 1 . Milk consumption (ml/pup) of both groups increased linearly over time $(P<0.001)$. When milk intake was expressed as $\mathrm{ml} /$ pup per $\mathrm{d}, \mathrm{Fe}+$ pups ingested significantly more milk than did $\mathrm{Fe}-$ pups $(P<0.001)$. However, when milk consumption was expressed on a bodyweight basis, $17 \mathrm{~d}$ Fe-deficient pups ingested $46.9 \%$ more milk than Fe-sufficient controls $(P<0.001)$. While control pups consumed significantly more energy $(\mathrm{kJ} / \mathrm{d})$ (Table 4$)$ than Fe-deficient pups $(P<0.001)$ when energy intake was expressed on a body-weight basis, only at day 7 did $\mathrm{Fe}+$ pups receive more energy than $\mathrm{Fe}-$ pups. $\mathrm{Fe}$ intakes, expressed 
Table 4. Energy intakes, iron intakes and feed efficiency of Fe-sufficient and Fe-deficient rat pups at 7, 12 and $17 d$ of age

(Mean values with their standard errors expressed per pup were obtained from seven pooled litter measurements (seven pups/litter))

\begin{tabular}{|c|c|c|c|c|c|c|c|}
\hline & \multirow{3}{*}{$\begin{array}{c}\text { Dietary } \mathrm{Fe} \\
(\mathrm{mg} / \mathrm{kg})\end{array}$} & \multicolumn{6}{|c|}{ Age of pup (d) } \\
\hline & & \multicolumn{2}{|c|}{7} & \multicolumn{2}{|c|}{12} & \multicolumn{2}{|c|}{17} \\
\hline & & Mean & SEM & Mean & SEM & Mean & SEM \\
\hline $\begin{array}{l}\text { Energy intake }{ }^{a \cdot b} \\
(\mathrm{~kJ} / \text { pup per } \mathrm{d})\end{array}$ & $\begin{array}{r}250 \\
8\end{array}$ & $\begin{array}{l}60 \cdot 5 \\
40 \cdot 8^{* *}\end{array}$ & $\begin{array}{l}2.3 \\
1 \cdot 9\end{array}$ & $\begin{array}{l}96 \cdot 6 \\
63 \cdot 6^{* * *}\end{array}$ & $\begin{array}{l}6 \cdot 7 \\
3 \cdot 5\end{array}$ & $\begin{array}{l}127 \cdot 0 \\
76 \cdot 3^{* * *}\end{array}$ & $\begin{array}{l}7 \cdot 0 \\
5 \cdot 1\end{array}$ \\
\hline $\begin{array}{l}\text { Energy intake } \\
(\mathrm{kJ} / \mathrm{kg})\end{array}$ & $\begin{array}{r}250 \\
8\end{array}$ & $\begin{array}{l}4200 \\
3600^{*}\end{array}$ & $\begin{array}{l}200 \\
200\end{array}$ & $\begin{array}{l}3700 \\
3200\end{array}$ & $\begin{array}{l}200 \\
100\end{array}$ & $\begin{array}{l}2900 \\
3400\end{array}$ & $\begin{array}{l}200 \\
300\end{array}$ \\
\hline $\begin{array}{l}\text { Feed efficiency }{ }^{a, b} \\
(\mathrm{~g} \text { gain/kJ intake) }\end{array}$ & $\begin{array}{r}250 \\
8\end{array}$ & $\begin{array}{l}0.030 \\
0.027\end{array}$ & $\begin{array}{l}0.003 \\
0.005\end{array}$ & $\begin{array}{l}0.026 \\
0.021\end{array}$ & $\begin{array}{l}0.004 \\
0.003\end{array}$ & $\begin{array}{r}0.024 \\
-0.005\end{array}$ & $\begin{array}{l}0.003 \\
0 \cdot 003\end{array}$ \\
\hline $\begin{array}{l}\text { Fe intake } \\
(\mu \mathrm{g} / \mathrm{d} \text { per pup })\end{array}$ & $\begin{array}{r}250 \\
8\end{array}$ & $\begin{array}{l}41 \cdot 9 \\
14 \cdot 4^{* * *}\end{array}$ & $\begin{array}{l}1.6 \\
0 \cdot 7\end{array}$ & $\begin{array}{l}67 \cdot 0 \\
22-4^{* * *}\end{array}$ & $\begin{array}{l}0 \cdot 6 \\
1 \cdot 2\end{array}$ & $\begin{array}{l}88 \cdot 0 \\
26 \cdot 8^{* * *}\end{array}$ & $\begin{array}{l}4 \cdot 9 \\
1 \cdot 8\end{array}$ \\
\hline $\begin{array}{l}\text { Fe intake } \\
(\mathrm{mg} / \mathrm{kg})\end{array}$ & $\begin{array}{r}250 \\
8\end{array}$ & $\begin{array}{l}2 \cdot 9 \\
1 \cdot 3^{* * *}\end{array}$ & $\begin{array}{l}0 \cdot 1 \\
0 \cdot 1\end{array}$ & $\begin{array}{l}2 \cdot 5 \\
1 \cdot 1 * * *\end{array}$ & $\begin{array}{l}0 \cdot 1 \\
0 \cdot 0\end{array}$ & $\begin{array}{l}2 \cdot 0 \\
1 \cdot 2 * * *\end{array}$ & $\begin{array}{l}0 \cdot 1 \\
0 \cdot 1\end{array}$ \\
\hline
\end{tabular}

Analysis of variance $(2 \times 3$ factorial $){ }^{a}$ significant $(P<0.05)$ time effect, ${ }^{b}$ significant $(P<0.05)$ Fe $\times$ time interaction. Comparisons between treatments were made using least significant difference tests. Differences between dietary treatments at each time were significant. ${ }^{*} P<0.05,{ }^{* *} P<0.01,{ }^{* * *} P<0.001$.

either as $\mu \mathrm{g} / \mathrm{d}$ or $\mathrm{mg} / \mathrm{kg}$ per $\mathrm{d}$, were significantly less among $\mathrm{Fe}-$ pups than control pups $(P<0.001)$.

\section{DISCUSSION}

Results from the present study provide evidence that maternal Fe deficiency affects the quality of milk ingested by the neonatal rat. Milk secreted by Fe-deficient dams contained less fat and $\mathrm{Fe}$ and was less energy-dense than milk from control dams. However, Fedeficient pups attempted to compensate for poor milk quality be increasing milk intake in late lactation. Despite obvious signs of morbidity, 17-d-old Fe- pups consumed significantly more milk than control pups when quantity ingested was expressed on the basis of body-weight ( 363 v. $248 \mathrm{ml} / \mathrm{kg}$ per $\mathrm{d}$ ).

Experimental evidence indicates that animals will eat to meet their energy and protein needs (Donaldson et al. 1956; Renner, 1964). Although milk samples from both control and experimental dams contained similar amounts of protein and constituent amino acids, samples from $\mathrm{Fe}$ - dams with less fat were less energy-dense. The observed increase in milk intake on day 17 by $\mathrm{Fe}$ - pups was likely in response to the reduced energy density of milk provided by $\mathrm{Fe}-$ dams. This observation is consistent with reports that, after 2 weeks of age, pups demonstrate the capacity to respond to a period of fasting or an energy deficit by increasing milk intake (Henning et al. 1979; Henning, 1981). Pups show their awareness of energy deprivation following a fasting period by quickly attaching to the teats of their mother on return to the nest and, when milk let-down is chemically blocked, by rapidly shifting among nipples. A similar transition period to adult feeding behaviour occurs in human infancy. Fomon et al. $(1969,1975)$ found that before $41 \mathrm{~d}$ of age, bottle-fed infants do not regulate their intake based on the energy density of formula provided. Regardless of the energy density of the formula fed, the volume of milk consumed during the first $41 \mathrm{~d}$ of life is relatively constant. After adult feeding behaviour is established, human 
infants suck to meet their energy needs and milk intake becomes inversely proportional to the energy density of the formula fed.

Except in early lactation (day 7), $\mathrm{Fe}$ - pups consumed an amount of energy per kg bodyweight that was similar to that of control animals (Table 4). In late lactation (day 17), however, $\mathrm{Fe}$ - pups showed negative energy efficiency ( $\mathrm{g}$ gain/kJ intake), indicating that energy consumed was not being utilized for growth and that body stores were being mobilized. While $\mathrm{Fe}$ - pups appeared to compensate for reduced milk energy by increasing milk intake, absolute energy requirements of $\mathrm{Fe}$ - pups may be greater than control pups (Dallman, 1986). If this were the case, energy requirements were not met by $\mathrm{Fe}$ - pups even though milk consumption was increased $(46 \%)$ to a level which achieved energy intakes similar to those of control pups.

Alternatively, changes in milk quality other than energy density may have been responsible for impaired growth of $\mathrm{Fe}-$ pups. In the present study, $\mathrm{Fe}$ - pups received less $\mathrm{Fe}$ than control pups throughout lactation despite the increased milk intake in late lactation. Results from animal studies show that $\mathrm{Fe}$ deficiency alone causes growth retardation (Beard et al. 1984; Martinez-Torres et al. 1984). Furthermore, Lanzkowsky et al. (1981) found that pups born to Fe-sufficient dams but nursed by Fe-deficient dams develop Fe deficiency as evidenced by depressed values for $\mathrm{Hb}$ and serum Fe on day 21 of lactation. We previously reported that sucking offspring develop signs of folate deficiency when nursed by $\mathrm{Fe}$ - dams and that $\mathrm{Fe}$ - dams secrete milk with decreased milk folate content (O'Connor et al. $1987 a, b$ ). Cellular depletion of folate likewise results in impaired growth (Baumslag et al. 1970; Iyenar \& Rajalakshmi, 1975; Rolschau et al. 1979). Results from this investigation do not permit an evaluation of the relative impact on the neonate of various changes in milk composition during maternal Fe deficiency; however, they do stress the importance of maintaining milk quality and the vulnerability of the sucking neonate.

Observations from the present and previous studies (Kochanowski et al. 1983; O'Connor, 1987a) suggest that Fe may serve an important function in the regulation of nutrient utilization by the mammary secretory cell. In the present study, we observed that milk from Fe-deficient dams has not only a reduced Fe content but a reduced lipid content. Maternal Fe deficiency also blocks preferential partitioning of folate to the mammary gland for secretion (O'Connor et al. 1987a). In the absence of Fe deficiency, regulatory mechanisms exist to maintain the nutrient composition of milk even at the expense of maternal reserves. For example, maternal metabolism may be depressed in undernourished lactating women (Prentice et al. 1981) and in lactating dairy cattle (Bauman \& Currie, 1980) allowing for increased nutrient partitioning to the mammary gland for milk synthesis and secretion.

In summary, results from the present study showed that Fe deficiency caused a decrease in the lipid, $\mathrm{Fe}$ and energy contents of milk. While increased milk intake by $\mathrm{Fe}-$ pups appeared to compensate for the reduced fat and energy contents of milk, it did not compensate for reduced milk Fe. In the light of present findings, the possible influence of maternal Fe deficiency on the nutrient composition of milk from human beings merits investigation.

The authors are grateful to Mrs Sandra Ramlet and Miss Lorie Ellis for their expert technical assistance. Special appreciation is extended to Dr Sandra Bartholmey for assitance with amino acid analyses. Supported in part by USDA Competitive Grant AG 84-CRCR-1-1493 and The Illinois Agricultural Experiment Station. 


\section{REFERENCES}

Bartholmey, S. J. \& Sherman, A. R. (1985). Journal of Nutrition 115, 138-145.

Bauman, D. E. \& Currie, B. W. (1980). Journal of Dairy Science 63, 1514-1529.

Baumslag, N., Edelstein, T. \& Metz, J. (1970). British Medical Journal i, 16-17.

Beard, J. L., Huebers, H. \& Finch, C. A. (1984). Journal of Nutrition, 114, 1396-1401.

Bergmann, K. E., Ziegler, E. E. \& Fomon, S. J. (1974). In Infant Nutrition, pp. 245-266 [S. J. Fomon, editor]. London and Toronto: W. B. Saunders.

Bothwell, T. H., Charlton, R. W., Cook, J. D. \& Finch, C. A. (1979). In Iron Metabolism in Man, pp. 7-43. Oxford, London, Edinburgh and Melbourne: Blackwell Scientific Publications.

Coward, W. A., Cole, T. J., Gerber, H., Roberts, S. B. \& Fleet, I. (1982). Pflügers Archiv 393, 344-347.

Dallman, P. R. (1986). In Annual Review of Nutrition, vol. 6, pp. 13-40 [R. E. Olson, editor]. Palo Alto, CA: Annual Reviews Inc.

Dallman, P. R., Siimes, M. A. \& Stekel, A. (1975). American Journal of Clinical Nutrition 33, 86-118.

Donaldson, W. E., Combs, G. F. \& Romoser, G. L. (1956). Poultry Science 35, 1100-1105.

Fomon, S. J., Filer, L. J., Thomas, L. N., Anderson, T. A. \& Nelson, S. E. (1975). Acta Paediatrica Scandinavica 64, 172-181.

Fomon, S. J. Filer, L. J., Thomas, L. N., Rogers, R. R. \& Proksch, A. M. (1969). Journal of Nutrition 98, $241-254$.

Henning, S. J. (1981). American Journal of Physiology 241, G199-G214.

Henning, S. J., Chang, S. P. \& Gisel, E. G. (1979). American Journal of Physiology 237, R187-R191.

Iyengar, L. \& Rajalakshmi. (1975). American Journal of Obstetrics and Gynecology 122, 332-336.

Jelliffe, D. B. \& Jelliffe, E. E. P. (1978). American Journal of Clinical Nutrition 31, 492-515.

Keller, R. P. \& Neville, M. C. (1986). Clinical Chemistry 32, 120-123.

Kochanowski, B. H., Smith, A. M., Picciano, M. F. \& Sherman, A. R. (1983). Journal of Nutrition 113, 2471-2478.

Lanzkowsky, P., Karayalcin, G. \& Miller, F. (1981). In Iron Nutrition Revisited-Infancy, Childhood, Adolescence, pp. 50-60 [F. Oski, editor]. Columbus, OH: Ross Laboratories.

Lucas, A., Gibbs, J. A. H., Lyster, R. L. J. \& Baum, J. D. (1978). British Medical Journal i, 1018-1020.

Martinez-Torres, C., Leets, I., Cobeddu, L., Layrisse, M., Dillman, E., Johnson, D. G. \& Brengelmann, G. L. (1984). American Journal of Physiology 246, R380-R383.

Menaker, L. \& Navia, J. M. C. (1973). Journal of Nutrition 103, 347-352.

Miranda, R., Saravia, N. G., Ackerman, R., Murphy, N., Berman, S. \& McMurray, D. N. (1983). American Journal of Clinical Nutrition 37, 632 640.

National Research Council (1978). Nutrient Requirements of Laboratory Animals no. 10, 3rd ed. Washington, DC: National Academy of Science.

O'Connor, D. L., Picciano, M. F., Sherman, A. R. \& Burgert, S. L. (1987a). Journal of Nutrition 117, $1715-1720$

O'Connor, D. L., Sherman, A. R. \& Picciano, M. F. (1987 b). Federations Proceedings 46, 895.

Picciano, M. F., Calkins, E. J., Garrick, J. R. \& Deering, R. H. (1981). Acta Paediatrica Scandinavica 70, $189 \cdots 194$

Picciano, M. F. \& Guthrie, H. A. (1976). Clinical Nutrition 29, 242254.

Prentice, A. M., Whitehead, R. G., Roberts, S. B. \& Paul, A. A. (1981). American Journal of Clinical Nutrition 34, 2790-2799.

Renner, R. (1964). Journal of Nutrition 84, 322-326.

Richterich, R. (1969). Clinical Chemistry, pp. 329-335. Basel Switzerland: Basier Purek und Verlagsanstalt.

Rolschau, J., Date, J. \& Kristoffersen, K. (1979). Acta Obstetrica et Gynecologicia Scandinavica 58, 343-346.

SAS Institute Inc. (1985). SAS User's Guide: Statistics, 5th ed. Cary, NC: SAS Institute, Inc.

Steel, R. G. D. \& Torrie, J. H. (1980). Principles and Procedures of Statistics : a Biometrical Approach, 2nd ed. New York: McGraw-Hill Book Co.

Timmen, H. \& Dimick, P. S. (1972). Journal of Dairy Science 55, 919-925.

Venkatachalam, P. S. \& Ramanathan, K. S. (1964). Journal of Nutrition 84, 38-42. 